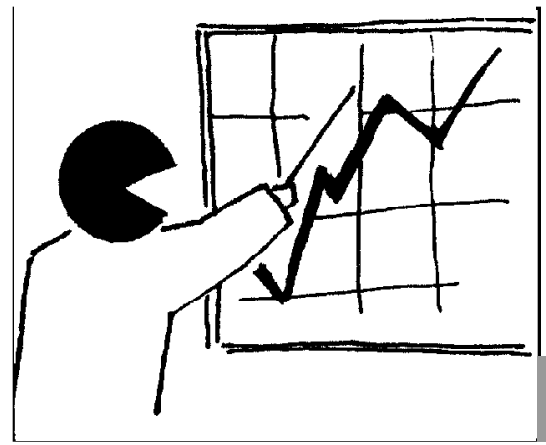

УДК 37.374.1
Мирослав КРИШТАНОВИЧ, доктор наук з державного управління, дочент, професор кафедри педагогіки і соиіального управління, Інститут права та психології Начіонального університету "Львівська політехніка", Уукраїна ORCID ID: 0000-0003-1750-6385 mf0077@ukr.net

\title{
МОЖЛИВОСТІ ВИКОРИСТАННЯ ІКТ У ПОЗАУРОЧНІЙ РОБОТІ ПРИ ВИВЧЕННІ ПРАВОЗНАВСТВА
}

\author{
Miroslav KRYSHTANOVICH, Doctor of Sciences in Public \\ Administration, Associate Professor Professor of the Department of \\ Pedagogy and Social Management, Institute of Law and Psychology \\ National University "Lviv Polytechnic", Ukraine
}

\section{POSSIBILITIES OF USING ICT IN OUTDOOR WORK IN LAW STUDY}

Розвиток і поступове впровадження в існуючу систему навчання нових інформаційно-комунікаційних технологій зумовили перегляд багатьох сталих класичних, методичних, дидактичних, педагогічних і методологічних уявлень про систему вивчення правознавства в загальноосвітній школі. Ефективність їх застосування в навчанні багато в чому залежить від того, наскільки методично грамотно і педагогічно виправдане було включення IКТ в структуру навчального процесу загальноосвітнього навчального закладу при вивчення правознавства у позаурочній роботі з можливостями використання Інтернет-технології. Зокрема, це стосувалось можливостей застосування інформаційно-комунікаційних технологій у позаурочній роботі при вивченні правознавства.

Ключові слова: IКТ, Інтернет, правознавство, 3ЗСО, учень, учитель, навчальний процес.

Summary. The development and gradual introduction into the existing system of teaching new information and communication technologies (hereinafter - ICT) have led to the revision of many established classical

C) М. Криштанович methodological, didactic, pedagogical and methodological ideas about the system of studying law in the secondary school. The effectiveness of the use of information and communication technologies in education largely depends on how methodologically and pedagogically justified their inclusion in the structure of the educational process of a general educational institution in the study of law in extra-curricular work with the use of ICT.

Key words: ICT, Internet, science of law, HII, student, teacher, learning process.

Мета: з'ясувати суть та значення інформаційно-комунікаційних технологій, які впроваджені в навчальний процес підготовки існуючої системи навчання правознавства в закладі загальної середньої школи.

Постановка проблеми в загальному вигляді. Упровадження у загальноосвітню школу сучасних засобів навчання на основі інформаційно-комунікаційних технологій зумовлює поступ нашого суспільства. Підвищення професійної компетентності вчителя - це розвиток інноваційної культури та рівня інформаційної компетентності (Рябовол, 2011). Найбільш ефективним $є$ поєднання традиційних та інноваційних форм i методів навчання правознавства 3 використанням інформаційно-комунікаційних технологій.

Аналіз досліджень і публікації. Вітчизняними та зарубіжними вченими В. Биковим, Н. Морзе, I. Робертом, Б. Гершинським В. Безугловим, Т. Дубовою, Ю. Жуком, О. Калігаєвою та іншими досліджувався освітній процес щодо ефективності та якості впровадження інформаційно-комунікаційних технологій у загальноосвітній школі. Ураховуючи актуальність даного питання, яке $\epsilon$ предметом нашого дослідження, пропонується ряд інновацій стосовно застосування інформаційно-комунікаційних технологій при навчанні правознавства в позаурочний час.

Виклад основного матеріалу дослідження. Перед педагогічною спільнотою постало питання вибору інформаційно-комунікаційного Інтернет-середовища, що дало б результативність у позаурочному навчанні, відрізнялося б суттєвим порядком будь-якого уроку, високим мотивуванням пізнавальної функції учнів, своєчасністю і конкретним сприянням усім, хто мав потребу у ній і міг користуватися перевагами інформаційно-комунікаційних технологій (далі - IКТ) навчання, що сприяють урізноманітненню освітніх ре- 
сурсів, високій якості методичних розробок, можливості миттєвого консультування (Інформаційно-комунікаційні технології.., URL: www.osvita.ua/schoo.).

Оптимізація організації навчального процесу та активізація діяльності учня в позаурочний час має здійснюватись за допомогою презентацій навчального матеріалу, фото і відеофрагментів, обміну повідомлень та документів через чат, електронну пошту. За таких умов учень мусить мати виклик на кожний урок від учителя, яке надсилається на е-пошту. Важливою вимогою як для учителя, так і для учня є наявність комп'ютеpa, підключення до Інтернету, вебкамери, мікрофона, навички роботи на комп'ютері, графічного планшета (для збереження наданого матеріалу).

Дана система розрахована на вільне переміщення учнів, можливість працювати в синхронному порядку. Іх забезпечують усім потрібним матеріалом, уводячи навчальні програми. Вони мають шанс встановлювати контакт $з$ учителем через систему IКТ школи, який відповідає на питання школярів, оцінює їх роботу.

До функцій інноваційних технологій належить: е-розклад уроків; ежурнал; поле утворення сторінки школи та своєї сторінки; е-бібліотека; мультимедійна бібліотека; е-словники; е-перекладач; здатність отримувати батьками детальну інформацію про успішність своєї дитини та проведення віртуальних батьківських зборів; проведення конкурсів, тестових завдань, олімпіад та віртуального репетиторства.

Передбачається, що під час проведення занять у позаурочний час переважна більшість навчального матеріалу з правознавства подається через Інтернет. Також взаємодія учасників навчального процесу має здійснюватися з використанням технічних і програмних засобів Інтернетмережі.

Діяльність освітньої практики учнів з використанням IКТ на заняттях правознавства в позашкільний час дозволяє (Терещченко, 2014):

- зробити такий процес цікавим, ураховуючи нову форму практики для школярів, а також із застосуванням мультимедійних можливостей новітніх комп'ютерів;

• вирішити питання очної освіти, забезпечити візуальним дидактичним матеріалом, щоб він став більше загальнодоступним для школярів завдяки використанню прийомів IТК, що зацікавить їх пошуковою діяльністю;

- відрізнити освітній процес навчання завдяки багаторівневим задачам, опрацюванню навчального матеріалу, користуючись практичними засобами сприймання інформації;

- самотужки розглядати й редагувати допустимі неточності, мати зворотний звязок з учителем, унаслідок чого вдосконалюються навички самовладання зі сторони учнів;

- здійснювати самостійну, визначену програмою навчання певну дослідну практику (підготовка виступів на учнівську конференцію, розробка презентацій та ін.), удосконалюючи в учнів академічну активність.

На підвалинах грунтовного аналізу практики роботи учнів за традиційною освітньою формою відповідно до навчального плану важливо розробляти основну структуру діяльності незалежної роботи в позаурочний час. Для цього слід ретельно сформувати задачі для окремої практики школярів, ураховуючи особливості використання електронних приладів з метою підтримки такої форми навчання. Тому необхідно брати до уваги те, що не всі форми самостійної роботи учнів можна автоматично перенести в електронне навчальне середовище. Це пояснюється тим, що вчителю може бракувати досвіду роботи в умовах застосування інформаційних технологій, що часом призводить до нечіткого розуміння всіх етапів підтримки учнів упродовж уроку. Учителю необхідно спроектувати весь цикл завдань за темами, що вивчаються, та запропонувати методичні рекомендації щодо підтримки діяльності учня. Особливий акцент слід приділяти правильноому оцінюванню навчальних досягнень учня в позаурочний час. Важливо врахувати внесок кожного у виконання програмного завдання 3 правознавства, або приймати рішення стосовно виставлення однієї і тієї ж оцінки всім учням групи.

Потрібно окремо розглянути питання зберігання результатів самостійної роботи учнів у позаурочний час. Це дозволить уникнути непорозумінь щодо справедливості оцінювання. Результати вивчення окремих питань 3 правознавства засобами IКТ необхідно узагальнювати, щоб потім вносити певні коригування.

Вважаємо, важливо виробити загальну стратегію діяльності педагогі- чного колективу або окремого вчителя 3 питань використання ЕЗНП щодо особливостей їх реалізації у викладанні правознавства в позаурочній час. Така стратегія залежить від низки факторів і може бути прийнята на основі загальної політики школи.

При виконанні учнем самостійної роботи з вивчення правознавчих дисциплін у позаурочний час 3 допомогою технічних засобів навчання (далі - ТЗН) вчителю слід забезпечити відповідний рівень надання їм допомоги та підтримки. Бажано не пропонувати завдання, виконання яких потребує багато часу, використання спеціального програмного забезпечення та інформаційних ресурсів, яких немає у наявності, або якими учень ще не володіє. Рівень завдань та технічної підтримки повинен відповідати рівню знань та вмінь учня. Для полегшення роботи стосовно використання інформаційно-комунікаційних технологій у процесі вивчення складових завдань 3 курсу правознавства в позаурочний час рекомендується кілька разів зробити ці задачі та, опираючись на свій педагогічний досвід, старанно обдумати результати власної практики в різних навчальних ситуаціях.

Для реалізації стратегії розробки завдань, що стосуються інформаційного пошуку, рекомендується (Рябовол, 2011):

- обгрунтувати перелік навчальних тем, у межах яких учень може здійснювати інформаційний пошук;

- сформувати перелік завдань;

- визначити, які завдання доцільно виконувати індивідуально, а які в малих групах (до складу малих груп, як правило, входять 3-5 учнів). До роботи у групі доцільно залучати учнів, які мають різний рівень знань. При цьому слід надавати відомості про оцінювання результатів роботи кожного учня або всієї групи. Вибір залежить від складу завдання, навчальних стратегій, якими користується учитель;

- необхідно регулярно ознайомлюватися з фондами електронних та інформаційних ресурсів, якими учні можуть скористатися в ході їх навчання у позаурочний час.

Зауважимо, що вчитель повинен знати відповідні електронні інформаційні ресурси, особливо ті, що представлені на сайтах рефератів, значно краще за учнів. Час та умови проведення позаурочних занять 3 
правознавства з використанням IКT потрібно планувати заздалегідь. Їх обговорення можна проводити в педагогічному колективі $33 \mathrm{CO}$ в режимі реального часу. Вважаємо, що вчителю доцільно здійснювати ведення каталога таких занять і з відповідними рекомендаціями, побажаннями для учнів. Необхідно здійснити колективне обговорення знайдених школярами он-лайнових варіантів вирішення навчальних завдань 3 предмета, проаналізувати доцільність їх використання в режимі ITH.

Можемо виділити певні особливості вивчення всього циклу правознавства $з$ допомогою IКТ у позаурочний час:

- більше грунтовне й абсолютне опанування правових переконань $\mathrm{i}$ правил, передбачених стереотипом освітньої практики;

- упорядкування систематичного надання освітнього матеріалу, та його послідовного дотримання;

- чимале використовування навиків із подібних дисциплін;

- застосовування ініціативних методів учення (Букач, 2007).

Грунтовне опрацьовування циклу дисциплін запобігає односторонній спеціалізації, котра в основному не відповідає визначеним вимогам та зацікавленням учнів. Суть цих дисциплін реалізовується як одна із складових сутностей закладу загальної середньої освіти.

Основною організацією освітньої практики 3 вирішенням реального питання в позашкільний час може бути:

- виставлення інформації учителем за сприянням IKT;

- побудова особистої (та у групах) роботи учнів на комп'ютері, 3 посібниками та іншими носіями інформації;

• незалежна практика з комп'ютером у випадку сприяння зі сторони вчителя у розв'язанні уточнювальних питань, подібностей, характеристик, порівнянь.

Поєднання незалежної роботи в позаурочний час може здійснюватись на засаді особистого комп'ютера $з$ представленням тексту посібника. Це, без сумніву, дає перспективу учням виробляти навички з виділенням головного в навчальному тексті, складати логічні ланцюжки, таблиці, виділяти спільне і відмінне у правових процесах, фактах.

Подібна конфігурація освіти для учнів старших класів дає їм право одержати багатосторонні теоретичні і практичні знання, уміння і навики щодо використання IКТ, підготувати себе до вдалого продовження навчання у ЗВО з відповідним напрямом.

Висновки та перспективи подальших досліджень. Практика відпрацювання учнями правового повідомлення за підтримкою IКТ у позашкільний час - це шлях до зростання їхньої пізнавальної активності. Тому так важливо чимало часу потрібно відводити на подібний урок.

Практика показує, що застосовування інформаційних систем на уроках правознавства в позаурочний час збагачує перспективи творчості як учителів, так і учнів, посилює зацікавленість до цих дисциплін, сприяє інтенсивності ходу навчання. Але не потрібно забувати і про спілкування з учителем.

Отже, використання IКТ має бути добре спланованим, допомагати у вихованні і навчанні учнів правової культури.

\section{СПИСОК ЛІТЕРАТУРИ}

Рябовол, Л. Т. (2011). Навчання правознавства учнів основної і старшої школи на засадах системного підходу. Збірник наукових праць Бердянського державного педагогічного університету, 2, 213-220.

Дишлєва, С. Інформаційно-комунікаційні технології (IКТ) та їх роль в освітньому процесі. URL www.osvita.ua/schoo.

Терещенко, О. Л. (2014). Інтегровані уроки як засіб формування цілісного наукового світогляду учнів під час навчання правознавства. Iсторія та правознавство, 6, 2-5.

Рябовол, Л. Т. (2011). Професійна компетентність учителя правознавства як умова формування правової компетентності учнів. Збірник наукових праць Уманського державного педагогічного університету імені Павла Тичини, (ч.1). Умань : ПП Жовтий, 1, 223-230.

Букач, А. (2007). Інформаційні та комунікаційні технології в освітній системі. Школа, 12, 5-31.

\section{REFERENCES}

Ryabovol, L. T. (2011). Navchannya pravoznavstva uchniv osnovnoyi i starshoyi shkoly na zasadakh systemnoho pidkhodu. Zbirnyk naukovykh prats' Berdyans'koho derzhavnoho pedahohichnoho universytetu, 2, 213-220.

Dyshlyeva, S. Informatsiynokomunikatsiyni tekhnolohiyi (IKT) ta yikh rol' v osvitn'omu protsesi. URL : www.osvita.ua/schoo.

Tereshchenko, O. L. (2014). Intehrovani uroky yak zasib formuvannya tsilisnoho naukovoho svitohlyadu uchniv pid chas navchannya pravoznavstva. Istoriya ta pravoznavstvo, 6, 2-5.

Ryabovol, L. T. (2011). Profesiyna kompetentnist' uchytelya pravoznavstva yak umova formuvannya pravovoyi kompetentnosti uchniv. Zbirnyk naukovykh prats' Umans'koho derzhavnoho pedahohichnoho universytetu imeni Pavla Tychyny, Uman' : PP Zhovtyy, 1, 223-230.

Bukach, A. (2007). Informatsiyni ta komunikatsiyni tekhnolohiyi v osvitniy systemi. Shkola, 12, 5-31.

Стаття надійшла 17.09.2019 p. 